\section{Response to: 'Correspondence on 'EULAR recommendations for the management of antiphospholipid syndrome in adults" by Gao and Qin}

We thank Gao and Qin ${ }^{1}$ for their interest in the 2019 European League against Rheumatism (EULAR) recommendations for the management of antiphospholipid syndrome (APS) in adults. ${ }^{2}$

The authors raised a question about the management of individuals 'with threatened abortion or threatened premature delivery, no history of delivery $<34$ th week of gestation and $<10$ th week of spontaneous miscarriage, but the results of laboratory tests show that antiphospholipid antibodies (aPL) are positive and other pathogenesis is not found'. In addition to recommendations for the management of women fulfilling the classification criteria for definite obstetric APS (premature birth $<34$ th week of gestation due to severe pre-eclampsia or eclampsia, $\geq 3$ unexplained spontaneous abortions $<10$ th week or $\geq 1$ unexplained fetal death $>10$ th week of gestation), EULAR recommendations for APS management have also addressed the non-criteria obstetric APS manifestations (section 9C). Non-criteria obstetric manifestations included the presence of two recurrent spontaneous miscarriages $<10$ th week of gestation or delivery $\geq 34$ th week of gestation due to severe pre-eclampsia or eclampsia. An expert opinion-based statement was made due to limited evidence since most studies reported on mixed populations of criteria and non-criteria pregnancy complications, indicating that treatment with low-dose aspirin (LDA) alone or in combination with prophylactic dose heparin might be considered based on individual's risk profile. For women with no history of pregnancy complications (with or without systemic lupus erythematosus (SLE) but with a high-risk aPL profile, it was stated that treatment with LDA (75-100 mg daily) during pregnancy should be considered (section 8, expert opinion). ${ }^{2}$

Gao and Qin commented that 'management recommendations for obstetric patients with APS before pregnancy are lacking' and they asked if 'it is necessary to start using LDA before pregnancy for patients at high risk of aPL'. EULAR Recommendations for the management of APS stated that LDA in obstetric APS should be preferably started prior to conception (section 9A). ${ }^{2}$ In their next point, Gao and Qin reported that in women with recurrent pregnancy complications despite combination treatment with LDA and heparin at prophylactic dosage, addition of hydroxychloroquine (HCQ) in the first trimester is considered' and they have asked 'whether it is necessary to start using HCQ 3 months before the next pregnancy since HCQ needs to be used 3 months in advance to reach the effective concentration'. EULAR recommendations stated that in women with recurrent pregnancy complications despite combination treatment with LDA and heparin at prophylactic dosage, increase of heparin to therapeutic dose or addition of HCQ or low-dose prednisolone in the first trimester may be considered (section 10). The evidence for the potential use of HCQ was based on two small observational studies with limited representativeness ${ }^{3}$ where no mention about HCQ initiation before conception was made. $^{45}$

Gao and Qin also commented that 'obstetricians tend to intensify monitoring and detect aPL regularly during pregnancy', and since 'studies have shown that the aPLs level will change dynamically during pregnancy', they asked whether 'these changes have any effect on our prescription'. This question was not included in our systematic literature review; however, current evidence from isolated studies addressing this issue does not support any changes in management practice based on aPL titre changes during pregnancy because although modest decreases in all aPL tests were observed during pregnancy, these changes were not associated with changes in pregnancy outcomes. ${ }^{6}$ Finally, Gao and Qin raised the question if it is necessary to monitor platelet changes during pregnancy' given that 'studies have shown that decreased platelet count may be an indicator of poor prognosis in patients with APS'. Regular blood testing during pregnancy is crucial in patients with APS to rule out potential APS complications manifested with thrombocytopenia, including hemolysis, elevated liver enzymes, low platelets (HELLP) syndrome and catastrophic APS.

We agree that more evidence is needed to address these questions that hopefully will be answered by the updated EULAR recommendations for APS management.

Maria G Tektonidou $\odot,{ }^{1}$ Angela Tincani, ${ }^{2}$ Michael M Ward $\odot^{3}$

${ }^{1}$ First Department of Propaedeutic Internal Medicine, National and Kapodistrian University of Athens, Athens, Attica, Greece

${ }^{2}$ Department of Clinical and Experimental Sciences, University of Brescia, Brescia, Italy

${ }^{3}$ Intramural Research Program, National Institute of Arthritis and Musculoskeletal and Skin Diseases, National Institutes of Health, Bethesda, Maryland, USA

Correspondence to Professor Maria G Tektonidou, First Department of Propaedeutic Internal Medicine, University of Athens, Athens, Attica 11527, Greece; mtektonidou@gmail.com

Handling editor Josef S Smolen

Contributors All authors contributed to the preparation of this correspondence.

Funding The authors have not declared a specific grant for this research from any funding agency in the public, commercial or not-for-profit sectors.

Competing interests None declared.

Patient and public involvement Patients and/or the public were not involved in the design, or conduct, or reporting, or dissemination plans of this research.

Patient consent for publication Not required.

Provenance and peer review Commissioned; internally peer reviewed.

(c) Author(s) (or their employer(s)) 2021. No commercial re-use. See rights and permissions. Published by BMJ.

\section{Check for updates}

To cite Tektonidou MG, Tincani A, Ward MM. Ann Rheum Dis Epub ahead of print: [please include Day Month Year]. doi:10.1136/annrheumdis-2021-220116

Received 15 February 2021

Accepted 16 February 2021

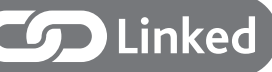

- http://dx.doi.org/10.1136/annrheumdis-2021-220092

Ann Rheum Dis 2021;0:1. doi:10.1136/annrheumdis-2021-220116

ORCID iDs

Maria G Tektonidou http://orcid.org/0000-0003-2238-0975

Michael M Ward http://orcid.org/0000-0003-1857-9367

\section{REFERENCES}

1 Gao R, Qin L. Correspondence on "EULAR recommendations for the management of antiphospholipid syndrome in adults". Annals Rheum Dis 2021. doi:10.1136/ annrheumdis-2021-220092

2 Tektonidou MG, Andreoli L, Limper M, et al. EULAR recommendations for the management of antiphospholipid syndrome in adults. Ann Rheum Dis 2019;78:1296-304.

3 Tektonidou MG, Andreoli L, Limper M, et al. Management of thrombotic and obstetric antiphospholipid syndrome: a systematic literature review Informing the EULAR recommendations for the management of antiphospholipid syndrome in adults. RMD Open 2019;5:e000924.

4 Mekinian A, Lazzaroni MG, Kuzenko A, et al. The efficacy of hydroxychloroquine for obstetrical outcome in anti-phospholipid syndrome: data from a European multicenter retrospective study. Autoimmun Rev 2015; 14:498-502.

5 Sciascia S, Hunt BJ, Talavera-Garcia E, et al. The impact of hydroxychloroquine treatment on pregnancy outcome in women with antiphospholipid antibodies. Am J Obstet Gynecol 2016;214:273.e1-273.e8.

6 Yelnik CM, Porter TF, Branch DW, et al. Brief report: changes in antiphospholipid antibody titers during pregnancy: effects on pregnancy outcomes. Arthritis Rheumatol 2016:68:1964-9. 